\title{
TANTANGAN IMPLEMENTASI NETRALITAS PNS (Kajian Kekerasan Simbolik dalam Pilkada)
}

\author{
M. Zaenul Muttaqin, Ilham dan Usman Idris \\ Universitas Cenderawasih, Jayapura, Indonesia \\ E-mail Korespondensi: zaenulmuttaqin99@gmail.com
}

\begin{abstract}
ABSTRAK. Pada arena pemilihan langsung, pegawai negeri sipil (PNS) selalu dianggap sebagai mesin politik yang memiliki peluang untuk mengumpulkan suara. Bourdieu memandang kekerasan simbolik terjadi secara laten, kekuasaan selalu membangun birokrasi dalam struktur hirarkis sehingga dalam pemilihan langsung PNS selalu dalam kondisi dilematis. Relasi politik, relasi sosial, relasi kultural PNS merupakan tiga aspek yang perlu dikaji lebih lanjut. Penelitian ini menggunakan metode kualitatif interpretatif. Bahan kepustakaan sebagai sumber data. Data dikumpulkan penelusuran literatur, jurnal buku, dokumen atau sumber data yang terkait dengan penelitian. Validasi data melalui pemeriksaan anggota atau memeriksa temuan menggunakan interpretasi secara tertulis dari akademisi bidang tersebut. Hasil penelitian menunjukkan bahwa reproduksi konjungtur terjadi secara berkelanjutan, keterlibatan PNS dalam pemilu dari orde lama hingga saat ini, di tengah pandemi harus dilihat dengan meta perspektif. Kekerasan simbolik terhadap PNS dapat ditekan dengan pencabutan hak suara. Tindakan ini diikuti dengan sanksi tegas pada sebelum dan sesudah pemilu.
\end{abstract}

Kata Kunci: Pemilu; Habitus; Kekerasan Simbolik.

\section{THE CHALLENGING OF CIVIL SERVANTS NEUTRALITY IMPLEMENTATION: Research of Symbiolic Violence at Head Election}

\begin{abstract}
In the arena of direct elections, civil servants (PNS) are always considered as a political machine who have opportunities of accumulate votes. Bourdieu viewed symbolic violence occur obsecurly, power always establish the bureaucracy in a subordinate structure so that in the direct elections the civil servants are always in problematic condition. Political relations, social relations, civil servant cultural relations are three aspects that need to be further examined. This research used interpretive qualitative method. Library materials as source of data. The data are collected by literature, book journals, documents or other data sources related to research. Data validation through member checking or examine the findings used interpretation in writing by an expert. The results of research show that the reproduction of conjuncture occur continuously, involvement of PNS in the elections from the old order to the present, during pandemic must be viewed from meta perspectives. Symbolic violence towards PNS can only be pressed by revocation of voting rights. This action was followed by forceful sanctions enforement at before and after the election.
\end{abstract}

Keywords: Election; Habitus; Symbolic Violence.

\section{PENDAHULUAN}

Pemilihan Kepala Daerah (Pilkada) langsung menjadi pintu yang membuka ruang demokrasi di Indonesia. Sejak Undang-Undang Nomor 22 tahun 1999 tentang Pemerintahan Daerah diimplementasikan, terjadi pergeseran prosedur. Terbukanya saluran aspirasi bagi masyarakat memilih langsung kepala daerahnya melahirkan figur pemimpin dengan keunggulan masing-masing. Format demikian menghasilkan praktik pendidikan politik dan kepemimpinan sekaligus. Putra daerah dianggap mengetahui secara spesifik keadaan wilayah termasuk potensi yang ada di dalamnya. Asumsi tersebut mengekspresikan putra daerah layak dan mampu mengelola kebutuhan sumber daya daerahnya, (Haris, 2014). Seiring waktu, calon kepala daerah dari jalur independen turut mewarnai demokrasi, yang sebelumnya bergantung pada keberadaan partai politik, (Ismail, 2014). Kebijakan ini tidak keliru, mengingat saluran rekrutmen kandidat dalam pilkada sebelumnya hanya diproyeksikan partai politik.
Kebijakan otonomi daerah secara konkrit merekonstruksi tiga agenda fundamental. Pertama, perubahan sentralisasi ke desentralisasi, mencakup kewenangan kepala daerah mengelola rumah tangga sendiri sesuai dengan potensi yang ada. Kedua, demokratisasi manajemen pelayanan publik yang menopang adanya transparansi. Ketiga, perubahan sistem pemilihan representatif ke pemilihan demokratis sehingga aspirasi terserap seutuhnya, (Prihatin, 2014). Secara ringkas, otonomi daerah mengafirmasi kesetaraan politis masing-masing daerah dengan keberagamannya, serta memangkas relasi pelayanan antara pemerintah dengan publik.

Dalam kontestasi pilkada, dikotomi politik dan pelayanan pada praktiknya seringkali taksa. Misi pelayanan untuk kepentingan umum dan mendekatkan pemerintah dengan publik berbaur dengan politik. Situasi tersebut mengayuhkan aparatur birokrasi yang bertugas menjalankan manajemen pelayanan rentan terpapar muatan politis. Pilihan Pegawai Negeri Sipil (PNS) untuk turut andil dalam arena politik disebabkan secara langsung beririsan 
dengan kariernya saat ini. Di Boyolali dan Lombok Utara, sebagian besar PNS ikut serta dalam suksesi salah satu kandidat, (Sudrajat \& Karsona, 2016).

Implikasi ketidaknetralan berdampak pada merosotnya kepercayaan publik kepada pemerintah. Pembangunan sistem kerja tidak profesional, memihak, serta mengabaikan asas netralitas berakibat pada melekangnya kepuasan masyarakat terhadap pemerintah, (Hartini, 2014). Gejala tersebut terjadi karena adanya celah bagi PNS menentukan hak pilih dalam proses pemilu. Undang-Undang Nomor 5 Tahun 2014 tentang Aparatur Sipil Negara yang dipertegas Peraturan Pemerintah Nomor 53 Tahun 2010 tentang Disiplin Pegawai Negeri Sipil nyatanya belum menunjukkan akan berkurangnya pelanggaran-pelanggaran disiplin dalam menjalankan tugas dan tanggung jawab, (Dompas, 2016). Terlebih, dalam birokrasi, PNS menjadi subsistem yang terkoneksi dengan kepentingan politik, (Sudrajat \& Karsona, 2016). Sinergitas kepala daerah dengan PNS dalam manajemen pemerintahan mengakibatkan PNS sarat muatan kepentingan. Bagi PNS yang tidak mendukung Pasangan Calon (Paslon) dalam Pemilihan Kepala Daerah (Pilkada) ataupun berseberangan dengan kepala daerah terpilih terancam hukuman. Sudirman Dalim (2010) dalam Lengkong et al., (2017) mengungkapkan bahwa Kurdi Martin, salah seorang PNS Banten yang terkena non-job karena tidak mendukung incumbent terpilih dalam kontestasi Pilkada. Kabupaten Siak Tahun 2011 menunjukkan hal serupa, dugaan kuat proses mutasi Wan Saiful Efendi selaku bagian Badan Kepegawaian Daerah (BKD) menjadi Camat Mandau penuh muatan politis usai tidak menaruh dukungan pada pemenang Pilkada, (Rayadi \& Erman, 2014). Realitas tersebut menunjukkan bahwa profesionalisme PNS dalam Pilkada belum lepas dari jeratan politis.

Hal ini terjadi karena kepala daerah berwenang mengangkat dan memutasi PNS dengan izin Menteri Dalam Negeri, (Marwi, 2016). Faktor dominan tersebut memengaruhi sikap pemilih PNS dalam menentukan sikap. Loyalitas mereka ditujukan untuk kepentingan karir. Dukungan para PNS di sisi lain pengaruh tekanan dari atas, sebagian lain karena tawaran program kandidat, memiliki ikatan hubungan keluarga, rekan sejawat dan faktor keinginan sendiri, (Marwis, 2011). Berdasarkan paparan tersebut, pilkada menyebabkan banyaknya fenomena tidak netralnya PNS dalam pilkada langsung menjadi hal yang lazim dari masa ke masa. Ancaman netralitas PNS dalam pilkada langsung pada tahun 2020 tetap mengintai. Kendati penyelenggaraan pilkada berbeda dari masa sebelumnya, karena diwarnai pandemi Corona Virus Disease 2019 (Covid-19).
Studi terdahulu menunjukkan bahwa politik dinasti menambah panjang rentetan kecacatan demokrasi langsung. Studi Bimantara, (2018) menunjukkan bahwa politik dinasti sebagai pola merambahnya lajur bisnis ke wahana keluarga termanifestasikan ke dalam politik praktis. Sifat politik dinasti yang terselubung membuatnya sulit diurai melalui perspektif sosial semata. Semenjak kebijakan otonomi daerah diberlakukan, penyebaran politik dinasti semakin sulit diidentifikasi, (Solihah, 2016). Berbeda dengan masa orde baru, fenomena rent seeking pada era reformasi merambat ke ranah lokalitas, aktor-aktor di tingkat lokal andil mengendalikan kekuasaan ekonomi menggunakan birokrasi. Selaras dengan hal tersebut, studi Pratama, (2017) di Kota Kendari menunjukkan bahwa, praktik pengendalian kekuasaan dalam tubuh birokrasi untuk kemenangan pilkada ditransmisikan melalui dua kategori, yakni dengan penempatan jabatan birokrasi tertentu dan aparatur sebagai mobilisator suara kontestan. Politisasi serupa terjadi pada mekanisme perekrutan penyelenggara pada lapisan bawah, mulai dari panitia penyelenggara pemilu, lurah dan camat.

Penelitian Mardiana, (2020) di Kabupaten Tanjung Jabung Timur, Jambi pada pilkada 2015 menunjukkan bahwa, PNS sebagai salah satu perangkat politis yang dikendalikan birokrasi dan partai politik untuk memperkuat kekuasaan kontestan pilkada. Longgarnya regulasi perekrutan dan kendurnya peran KPU di level bawah menyebabkan riskannya penyelewengan demokrasi seperti penempatan PNS sebagai bagian penyelenggara pemilu. Kompleksitas masalah tersebut menjadi tantangan besar pilkada pada masa pandemi yang mengatur saluran media sosial sebagai sarana utama di tengah pembatasan interaksi fisik. Keterlibatan PNS dalam Pilkada terjadi karena lemahnya kendali pengawasan aktifitas media sosial, (Khoiriyah \& Syarifudin, 2020). Apabila ditinjau dari segi peraturan, aktifitas media sosial PNS belum diungkap secara spesifik, sementara implementasi kebijakan pengawasan selama ini terpusat pada aktifitas PNS di ranah lingkungan fisik. Pada sisi lain, kebutuhan hidup masyarakat pada masa pandemi sulit dipenuhi, sehingga berjalannya pilkada berpotensi menyuburkan tindak kecurangan, seperti praktik pendulangan dukungan menggunakan uang maupun bentuk barang, (Ristyawati, 2020). Situasi ini menyebabkan parameter pengawasan muatan politis PNS sulit untuk ditentukan secara ideal.

Pada masa pandemi, kampanye kandidat pilkada dialihkan melalui media sosial. Mekanisme yang ada dalam media sosial seseorang merupakan representasi motif dalam keseharian, (Sudibyo, 2019). Media sosial sebagaimana arena sosial yang memuat pertarungan pelbagai kepentingan, sebagai 
pantulan strategi untuk mentransmisikan peran individualnya, (Riawanti, 2017). Sehingga akar aktifitas media sosial PNS dapat digali lebih dalam melalui perspektif kebijakan untuk menelusuri konteks dan entitas sosialnya.

Penelitian ini bertujuan untuk mengurai dan menganalisis kekerasan simbolik terhadap PNS yang terperangkap dalam politik dinasti maupun politisasi birokrasi. Penelitian ini melengkapi riset terdahulu yang banyak mengungkap praktik politisasi briokrasi melalui perspektif aturan dan menempatkan PNS sebagai klien dalam skema politik dinasti. PNS terjebak pada pilihan dilematis antara loyal kepada pimpinan atau patuh terhadap tuntutan netral yang menyangkut profesionalitasnya dalam birokrasi pelayan publik. Dalam arena pilkada, pilihan dilematis ini terjadi dengan determinasi semu atau terselubung, tetapi dampaknya terhadap karir sebagai PNS dapat diprediksi dengan mudah setelah pilkada.

Kajian kekerasan simbolik penelitian ini mencakup dampak relasi politik, sosio-kultural, serta praktik media sosial PNS. Kekerasan simbolik terjadi apabila ada pranata yang dapat dipergunakan untuk melanggengkan kekuasaan secara halus dan terselubung, tetapi diakui ada dalam kerangka sosial, (Riawanti, 2017). Prinsip kekerasan simbolik mengacu pada adanya pertukaran yang biasanya dikemas dalam bentuk balas jasa. Penelitian ini mensintesiskan teori kekerasan simbolik yang dikembangkan Bourdieu dengan peran-peran aktor kebijakan dalam implementasi peraturan netralitas PNS, sehingga menemukan strategi yang tepat dalam meminimalisir kendala netralitas PNS dalam kontestasi Pilkada di masa mendatang.

\section{METODE}

Penelitian ini menggunakan metode penelitian Kualitatif dengan pendekatan interpretatif. Sumber data penelitian ini berasal dari bahan pustaka yang berkaitan dengan tema penelitian. Pengumpulan data dengan menghimpun literatur, buku, jurnal, dokumen atau sumber data lain yang bertautan dengan penelitian. Selanjutnya dilakukan cross check data dari sumber utama maupun komparasi dengan sumber lain untuk menguji validitas data.

Analisis data dilakukan saat pengumpulan data maupun setelah pengumpulan data berupa reduksi, penyajian dan verifikasi data. Pemeriksaan keabsahan data dilakukan dengan member checking atau pengecekan temuan dengan interpretasi secara lisan dan tertulis terkait penelitian kepada pakar, (Creswell, 2009; Hamzah, 2020; Moleong, 2005). Adapun member checking dalam penelitian ini melalui diskusi panjang dan terus-menerus untuk menguji data penelitian bersama Ibu Vince Tebay selaku akademisi Administrasi Publik Universitas Cenderawasih yang memiliki wawasan luas terkait kebijakan publik dan Ibu Ivonne Poli selaku Akademisi Antropologi yang menguasai gagasan Bourdieu.

\section{HASIL DAN PEMBAHASAN}

Pemikiran Bourdieu tentangkekerasan simbolik dalam penelitian ini menunjukkan konsep modal terakumulasi melalui investasi. Kemudian modal ini terdistribusi kepada yang lain sehingga memberi keuntungan bagi pemilik sesuai kesempatan dan operasi penempatannya, (Mahar \& Harker, 2010). Modal terbagi menjadi empat bagian, yakni modal sosial, modal simbolik, modal budaya, dan modal ekonomi.

Pada arena pilkada langsung, birokrasi dan PNS selaku sumber daya manusia didalamnya kerap dianggap sebagai elemen produksi kekuasaan. Pilkada membentuk realitas PNS mesti terlibat dalam politik atau dukung-mendukung pasangan calon (Paslon). Aspek modal sosial dan modal simbolik yang dimiliki PNS dengan demikian terbatas oleh lingkungan kerja. Fenomena tersebut mengindikasikan PNS berada pada posisi subordinat dan inferior.

Struktur objektif dalam pilkada langsung melahirkan situasi yang tidak otonom. Struktur dalam konteks pilkada merupakan rangkaian kausalitas yang ditandai oleh kelas sosial yang berbedabeda. Lapisan ini diantaranya, partai politik sebagai pelaku utama dalam menyaring dan mengendalikan paslon yang berkompetisi di arena pilkada, kemudian masyarakat selaku pemilih menjadi target positioning, (Sudrajat \& Karsona, 2016). Pola rekrutmen demikian merupakan gejala demokrasi borjuis karena didominasi elit, Therborn (1978) dalam (Alamsyah, 2012). Cara kerja kekuasaan yang populis dan inkremental mengakibatkan langgengnya tekanan terhadap birokrasi. Secara fungsional, PNS terintegrasi dalam struktur, tidak lepas dari kekuasaan menjadikannya rentan terhadap kekerasan laten. Salah satu bentuk yang terjadi di Indonesia adalah adanya ancaman kepada PNS untuk tunduk pada kandidat yang berasal dari pemimpin saat ini,(Alamsyah, 2012). Ancaman tersebut berupa adanya legitimasi politis incumbent yang kembali mengajukan diri dalam kontestasi pilkada, (Dharmaningtias, 2020). Sehingga karir PNS dalam ancaman serius mengingat Pejabat Pembina Kepegawaian (PPK) dipegang kepala daerah.

Determinasi semu padagilirannyaterpatri dalam ingatan sebagai bagian politik praktis, membentuk realitas sehingga PNS terpaksa berpartisipasi pada arena pilkada langsung. Prestis PNS dalam 
lingkungan masyarakat menjadi agen yang dapat mendistribusikan kekuatan modal sosial dan modal simbolik. Keterlibatan PNS dalam suksesi pilkada langsung dapat membuka lajur demokrasi di satu sisi, tetapi dengan manipulasi identitas sosialnya, PNS berpotensi memobilisasi masyarakat untuk memilih salah satu kandidat. Modal sosial, sebagaimana pandangan Bourdieu dikatakan sebagai sumber daya aktual dan potensial, berasal dari jaringan sosial yang terlembagakan serta berlangsung sustainable. Pada sistem sosial, PNS memiliki peran persuasif dalam memengaruhi opini masyarakat lingkungan tempat tinggalnya.

Sementara modal simbolik, menurut pandangan Bourdieu memungkinkan aktor menggambarkan bentuk-bentuk kepentingan atas kekuasaan. Keberadaan PNS di tengah masyarakat telah terlembagakan sebagai kelompok dengan posisi yang lebih tinggi dari kelas sosial pada umumnya. Status, gaya, cara berbicara PNS, adalah hal yang formatif dan sebagai satu kesatuan. Peran simbol dapat diberdayakan untuk mendapatkan tempat. Status yang melekat pada PNS menginjeksi sebuah kontrol pada lingkungan sosial. Tampak mampu berbicara dengan percaya diri, dengan permainan bahasa tertentu, kendati sulit dipahami, tingkat penerimaan yang luas terhadap simbol birokrasi membuat retorika politis dapat diterima sebagai sebuah kebenaran dan patut dipercaya. Kelompok, termasuk komunitas masyarakat semacam abstraksi belaka, individu dapat berbicara menggunakan simbol publik dan, membawa hasil eksistensi atau pengakuan bahwa individu tersebut adalah bagian dari komunitas, (Snook, 2009).

\section{A. Relasi Birokrasi dan Politik}

Kajian penyatuan birokrasi dan politik telah diungkapkan dalam paradigma administrasi publik. Peran birokrasi dan politik ini terwadahi dalam tahap perumusan kebijakan publik. Birokrasi memiliki perkakas kekuasaan yang lengkap dalam penyusunan agenda kebijakan, dan seringkali mengelola kepentingan. Birokrasi publik dalam lingkup pembuatan dan pelaksanaan kebijakan mengemban nilai tawar. Pertarungan persepsi dalam perumusan kebijakan menempatkan eksistensi birokrasi sebagai lembaga politik. Rel dialektis antar kepentingan baik birokrasi dengan lembaga legislatif umumnya berangkat dari kehendak penyelesaian masalah publik. Paradigma administrasi negara secara keilmuan telah memisahkan fungsi legislatif dan eksekutif secara tegas. Relasi birokrasi dengan politik praktis bertemu pada proses perumusan kebijakan yang menjadi ranah pertarungan kepentingan. Birokrasi berjalan beriringan dengan pelaksanaan kebijakan, (M. H. Basri, 2017; Ramadhanti, 2018). Birokrasi menghubungkan instrumen hipotesis penerimaan misi negara sebagai pelayan publik. Sebagaimana gagasan Weber mengenai birokrasi ideal dimana sistem politik dan konteks sosial masyarakat mengkristal, (Gedeona, 2013).

Pada perjalanannya dikotomi birokrasi dan politik dimulai pada tahap pelaksanaan kebijakan, karena tujuan birokrasi dibentuk adalah untuk kesejahteraan masyarakat. Tujuan tersebut akan sulit dicapai apabila proses politik tetap merambah ke dalam sistem birokrasi. Frederickson mengungkap adanya ancaman dalam birokrasi apabila politik diartikan secara luas sampai pada ritme pelaksanaan kebijakan. Birokrasi ditempatkan pada posisi nonformal dalam proses tersebut. Artinya, moralitas kepaduan politik dengan birokrasi tersentral pada aspek perumusan kebijakan publik. Kenyataannya, kekuasaan politik yang terjadi di Indonesia masih arbitrer. Kekuasaan politik bekerja secara sistematis untuk menekan struktur birokrasi.

Pada awal orde lama, hadirnya politik dalam birokrasi eksis, maklumat X Mohammad Hatta pada 16 Oktober 1945 menandai kemunculan beragam partai politik. Elit-elit parpol tersebut berada dalam kabinet. Hal ini menandai permulaan politisi menempati ruang birokrasi, dimana sebagian besar elit parpol menjabat menteri. Kemudian berlanjut pada masa pemerintahan orde baru. Birokrasi diposisikan sebagai instrumen mobilisasi massa, mensejajarkan pegawai negeri dengan institusi militer dan partai golongan karya. Objektivisme memperlakukan PNS sebagai anak kandung pemerintah, wajib tunduk dan menggerakkan masyarakat mendukung pemerintah, (Gedeona, 2013).

Terdapat beragam kerawanan ketika birokrasi terlibat dalam politik. Munculnya intervensi politik dalam penempatan jabatan-jabatan birokrasi akan memicu tindakan-tindakan penyelewengan. Legitimasi politik memiliki potensi menggoyahkan sistem karier dan rekrutmen. Dikotomi politik dan birokrasi di Indonesia menyebabkan ketidakjelasan batas antara posisi birokrasi sebagai pelayan masyarakat dengan aktor politik. Penyalahgunaan wewenang, terabaikannya pelayanan publik, penggunaan fasilitas publik untuk mendukung afiliasi politik selalu mewarnai birokrasi menjelang pemilu. Fakta ini membuktikan bahwa sistem pemerintahan belum memisahkan secara tegas antara jabatan politik dan domain politik, (Rakhmawanto, 2017). Keterlibatan birokrasi dalam politik membuat terjadinya disposisi yang berpihak pada kepentingan tertentu. Hal ini tidak lepas dari fakta bawa birokrasi memiliki otoritas dalam mengalokasikan dan mendistribusikan sumber-sumber yang dimilikinya yang mereduksi posisi birokrasi sebagai lembaga publik menjadi lembaga yang lebih menguntungkan sebagian kelompok, (Daniarsyah, 2015). 
Penerbitan Undang-Undang Nomor 5 Tahun 2014 tentang Aparatur Sipil Negara memuat Pejabat Pembina Kepegawaian menjadi kewenangan pejabat politik sehingga PNS terbelenggu dari roda politik yang diusung parpol dan paslon (Daniarsyah, 2015). Integritas dan profesionalisme belum melembaga dalam diri seorang PNS. Hal ini terjadi karena makna simbolik "alat negara" beralih peyoratif menjadi "mesin kuasa". Wewenang yang melampaui batas, ditambah peran yang strategis mengakibatkan gejala demoralisasi pada PNS sering terjadi, (Yuniningsih, 2018).

\section{B. Pilkada dalam masa Pandemi: Demokrasi Semu}

Arena kontestasi pilkada sebelum pandemi Corona Virus Disease 2019 (Covid-19) selalu identik dengan keterlibatan birokrasi dan PNS di dalamnya dalam memberi dukungan terhadap salah satu kandidat. Demokrasi langsung dalam kerangka tersebut merupakan bagian dari praktek demokrasi buram yang transaksional dan koruptif, (Arrsa, 2014; Yusriwan et al., 2018). Dengan adanya pandemi Covid-19, pilkada serentak tertunda hingga 9 Desember 2020. Dengan pertimbangan pandemi, Pemerintah kemudian menerbitkan Peraturan Pemerintah Pengganti Undang-Undang (PERPPU) Nomor 2 Tahun 2020 tentang Perubahan Ketiga Atas Undang-Undang Nomor 1 Tahun 2015 tentang Penetapan PERPPU No. 1 Tahun 2014 tentang Pemilihan Gubernur, Bupati Dan Walikota Menjadi Undang-Undang Kendati demikian, berdasarkan catatan Ombudsman, pilkada dalam masa pandemi tidak memiliki perubahan signifikan dengan skema sebelumnya, (Watra, 2020). Hal ini merujuk pada ketersediaan anggaran pilkada maupun Sumber Daya Manusia (SDM) penyelenggara. Proses pelaksanaan pilkada di tengah pandemi berpotensi memantik terjadinya maladministrasi. Adrianus Meliala selaku Anggota Ombudsman mendesak pemerintah dan penyelenggara pemilu agar mengubah aturan, anggaran dan SDM penyelenggara dalam masa pandemi, (Watra, 2020).

Sementara relasi kuasa di tingkat lokal dipicu oleh terbitnya Undang-Undang Nomor 32 Tahun 2004 yang diamandemen Undang-Undang Nomor 12 Tahun 2008 tentang Pemerintahan Daerah. Peraturan tersebut menjadi desain desentralisasi yang dipadukan dengan Otonomi Daerah sebagai petunjuk keleluasaan daerah untuk mengelola wilayahnya secara mandiri. Kendati demikian, lemahnya aspek netralitas birokrat memudarkan nilai-nilai normatif yang diusung hukum positif, karena tidak adanya batasan porsi kewenangan terhadap pejabat politik yang berada di tampuk hirarkis birokrasi. Sementara kontrol pusat ke daerah melemah dengan kehadiran shadow state yang terbentuk orang kuat lokal, kemuculan informal economy, (Agustino, 2017). Informal economy terungkap dengan terlebih dahulu mengenal tipologi birokrasi yang menempatkan PNS. Birokrasi sebagai mesin negara (state michenary) dan cerminan kondisi masyarakat suatu negara, (Martini, 2010). Sehingga bekerjanya birokrat bergantung pada kondisi sosial ekonomi masyarakat. Otonomi daerah selain membawa manfaat positif juga melahirkan dampak negatif seperti dominasi lokal berdasarkan jabatan tertentu seseorang dalam birokrasi pemerintahan. Kekerasan simbolik berpijar pada karakteristik kultural dan sosial pada masyarakat dan merupakan implikasi pengaruh shadow state pada aras lokal. PNS dalam pranata demikian berada pada posisi subordinatif yang rentan terpapar politisasi birokrasi.

Kerentanan adanya penyelewengan terhadap pilkada langsung di masa pandemi bukan tanpa alasan. Berdasarkan data Indeks Kerawasan Pemilu (IKP) Bawaslu, pengaruh relasi kuasa di tingkat lokal terhadap ancaman pelanggaran pilkada mencapai $56,31 \%$ dengan 56,69\% pelanggaran didominasi ASN, TNI, Polri, (Hafidz et al., 2020). Data tersebut dipertegas prakondisi pemetaan implikasi malpraktik dan pelanggaran pilkada di masa pandemi yang akan menyelenggarakan 9 pemilihan gubernur, 224 bupati dan 37 walikota. Strategi kampanye kontestan pilkada bergeser ke penggunaan teknologi internet yang tentunya memberatkan kontestan independen. Teknologi internet, terutama media sosial riskan menjadi wahana kampanye hitam yang menyudutkan lawan politik (Nisa et al., 2020). Munculnya kampanye hitam bersahutan dengan merebaknya berkembangnya buzzer politik dalam pemilu beberapa tahun terakhir (Sugiono, 2020).

Peran buzzer politik di Indonesia diungkapkan Lipson (2018) memiliki kemampuan mendongkrak popularitas seorang kandidat pemilu, sehingga kontestan yang memiliki biaya membayar buzzer berpeluang lebih besar memenangkan pemilu (Sugiono, 2020). Bebasnya pembuatan akun media sosial anonim menyebabkan sporadisnya kampanye hitam yang kerap dimotori buzzer politik ini (Hidayat, 2020). Pada pihak lain, kontestan petahana terindikasi melakukan malpraktik kampanye terselubung dengan bantuan sosial menggunakan nama pribadi, (Wasisto \& Prayudi, 2020).

Pilkada yang dijadwalkan pada akhir tahun 2020 tentu jadi pekerjaan berat bagi KPU selaku penyelenggara. Bahwasanya, penyelenggaraan pilkada dalam masa pandemi mesti mengacu pada protokol kesehatan di seluruh wilayah bersangkutan. Hal ini akan menyebabkan pembengkakan anggaran, mengingat komposisi pilkada akan berlangsung di ratusan tempat. Sehingga KPU mesti terus 
mengkampanyekan protokol kesehatan pada titiktitik tersebut kepada publik. Kemudian, ketaatan aspek keadilan dan transparansi dalam setiap tahapan penyelenggaraan. KPU dan Bawaslu dituntut untuk mampu menjaga Keseimbangan peserta dan pendukungnya. Upaya tersebut didukung oleh pentingnya revisi UU No. 10 Tahun 2016 tentang Pilkada,(Wasisto \& Prayudi, 2020).

\section{Kekerasan Simbolik: Legitimasi Kekuasaan dan Patuh pada Aturan}

Kekerasan simbolik terjadi dengan adanya ranah untuk medistribusikan modal. Ranah birokrasi dalam dikotomi ini mengejawantahkan PNS berada dalam posisi dilematis. PNS dijadikan sebagai alat kekuatan politik tertentu karena ancaman seperti nonjob selalu mengintai posisi mereka saat ini. Kekerasan tidak terjadi secara vulgar. Penanaman pengaruh kuasa biasanya terjadi secara laten (Riawanti, 2017). Sehingga loyalitas dan kepatuhan PNS menentukan posisi mereka pasca pilkada, (Leleng et al., 2018).

Aturan netralitas berhadapan dengan suprastruktur birokrasi yang di dalamnya PNS memiliki kedekatan dengan calon petahana dalam pilkada. Penerbitan Undang-Undang Nomor 5 Tahun 2014 tentang Aparatur Sipil Negara telah mengatur Pejabat Politik sebagai pengatur Pejabat Pembina Kepegawaian, sehingga terdapat dualitas yang dilematis pada aturan tersebut terutama apabila dikaitkan dengan netralitas yang hendak dibangun pada diri PNS dalam kontestasi pilkada. Sebagaimana temuan keterlibatan Sekretaris Daerah (Sekda) di Tulungagung (Budiono, 2019). Kemudian keterlibatan Camat Sambirejo Kabupaten Sragen pendukung calon petahana yang masih memiliki ikatan keluarga, (Sutrisno, 2019). Keterlibatan PNS dalam arena pilkada tidak lepas dari karier birokrasi. PNS yang tidak mendukung petahana dalam pilkada terancam mutasi, (Razak, 2015).

Dalambirokrasi,PNS dipersepsikansebagai alat politik untuk mendulang dukungan, bahkan memiliki peran strategis sebagai mobilisator massa. Posisi inferior PNS dalam pemerintahan mengindikasikan terjadinya kekerasan simbolik. Praktek mobilisasi birokrasi bagi kemenangan kandidat calon tetap terjadi (Budiono, 2019; Prayitno, 2011). Selaras dengan pendapat Bourdieu, habitus yang ada pada sosok birokrat dalam proses yang panjang membuat PNS terjebak dalam permainan politik praktis.

Bourdieu berpandangan bahwa agen kekuasaan mampu membatasi praktik melalui manipulasi seperangkat aturan, (Riawanti, 2017). Pada arena pilkada, agen utama yang memiliki peran besar adalah parpol. Dengan superioritasnya, tidak sedikit parpol yang menjangkau PNS atau birokrat untuk turut serta mengkampanyekan peserta pilkada. Atmosfer pilkada membuat posisi PNS berada dalam situasi tidak menguntungkan. Karier sebagai PNS adalah pertaruhan terbesar sehingga secara laten mereka berpihak pada salah satu peserta pilkada. Tanggapan PNS terhadap habitus adanya ancaman yang mengintai jika bersikap netral bisa disertai perhitungan strategis yang dikomparasikan dengan tujuan pada harapan masa mendatang.

Loyalitas PNS dalam pilkada diantaranya karena faktor hubungan keluarga, ambisi karier jabatan, ambiguitas peraturan netralitas PNS, dan lemahnya penegakan hukum, (Sutrisno, 2019). Berdasarkan klasifikasi tersebut, arena pilkada membuat PNS diidentifikasi jadi alat suplai dukungan salah satu kontestan. Sehingga alokasi modal simbolik PNS berbeda pada arena masyarakat dengan arena birokrasi.

Kenyataan seperangkat oposisi yang ada dalam arena pilkada dilihat sebagai konjungtur, atau gabungan peristiwa yang tidak terpisah satu sama lain. Realitas PNS dalam kehidupan masyarakat dianggap golongan yang sejajar dengan priyayi. Kelas sosial tersebut tidak lepas dari habitus sejarah di masa lalu bahwa PNS disetarakan dengan priyayi dan lembaga pemerintah. Pada masa orde baru, PNS secara otomatis merupakan resonansi suara pemerintah, sehingga masyarakat menganggap PNS sebagai kelas sosial yang secara langsung terhubung dengan sistem politik pemerintah.

Secara psikologis, PNS sebagai bagian dari pemerintah mengawetkan habitus memori komunitas masyarakatbahwa seorangPNSberadapadatingkatan lebih tinggi dan diasumsikan lebih memahami sistem politik praktis. Seringkali secara tidak langsung satu komunitas masyarakat mempertimbangkan interpretasi kandidat yang akan maju dalam pilkada melalui persepsi PNS. Dengan interaksi yang tidak terpisah dengan komunitas masyarakat, baik melalui forum-forum tidak resmi maupun kegiatan sosial lainnya, sedikit kemungkinan seorang PNS abai menyatakan pendapatnya. Sehingga dengan sendirinya seorang PNS memposisikan diri sebagai agen yang mengalokasikan modal simbolik ke tengah masyarakat. Tidak jarang bahkan dalam alokasi ini PNS memanipulasi simbol-simbol berupa bahasa selaku representasi pemerintah.

Pada siklus kebijakan publik, kegiatan politis terbatas sampai tahap perumusan kebijakan. Sementara secara aturan, sanksi pelanggaran netralitas PNS dalam UU No. 5 Tahun 2014 tentang Aparatur Sipil Negara maupun PP No. 53 Tahun 2010 tentang Disiplin Pegawai Negeri Sipil belum menyentuh aspek moralitas PNS. Hal ini ditambah ambiguitas regulasi yang ada. Siklus kebijakan yang mengisyaratkan politik terbatas pada formulasi kebijakan dengan 
demikian menjadi bias apabila meninjau UU No. 5 tahun 2014 yang menyiratkan Pejabat Pembina Kepegawaian berasal dari pejabat politik. Sehingga sanksi terhadap PNS yang melanggar netralitas pada masa pilkada, memiliki potensi bebas hukuman disiplin apabila sebelumnya mendukung kepala daerah terpilih, (Sutrisno, 2019). Kondisi tersebut sesuai dengan pandangan Bourdieu, stimulasi simbolik berperan ketika menghadapi agen yang dikondisikan untuk mengenalinya, (Zulhair, 2018). Pendapat ini kemudian dipertegas Weber yang mengatakan aturan sebatas prinsip sekunder yang berfungsi ketika kepentingan tidak tercapai, (Riawanti, 2017).

Keterlibatan PNS dalam arena pilkada menjadi rahasia umum sejak lama. Di tengah pandemi Covid-19, keikutsertaan PNS mengusung paslon dalam pilkada menjadi semakin menggeliat. Hal ini karena aturan kampanye dalam masa pandemi diharuskan secara daring. Mekanisme daring dapat dijadikan sarana kampanye terselubung oleh paslon yang tidak menutup kemungkinan peranan PNS. Temuan Bawaslu menunjukkan bahwa hingga 12 Juli 2020, dukungan PNS terhadap peserta pilkada sejumlah 6.492 yang tersebar di 79 kabupaten atau kota yang menggelar pilkada (Pradana, 2020). Sedangkan KASN menemukan jumlah pelanggaran PNS sebanyak 283 orang. Sebagian besar PNS yang terlibat menjabat sebagai Pimpinan Tinggi, dengan persentase 36 persen (Ramadhan, 2020). Motif pelanggaran netralitas berpijak pada unsur hirarki organisasi yang memerlukan loyalitas PNS kepada atasan secara struktural. Situasi ini selaras dengan pandangan Russell, orang-orang yang menganggap politik sebagai hal rumit, secara alamiah akan bersikap patuh pada perintah pimpinan (Russell, 2019).

Undang-Undang Nomor 5 Tahun 2014 tentang Aparatur Sipil Negara yang dipertegas Peraturan Pemerintah Nomor 53 Tahun 2010 tentang Disiplin Pegawai Negeri Sipil telah menggariskan PNS sebagai pelayan masyarakat yang profesional, jujur dan adil dalam menyenggarakan tugas negara, pemerintahan dan pembangunan. Undang-Undang Nomor 5 Tahun 2014 tentang Aparatur Sipil Negara secara garis besar telah memuat sistem merit, yakni konsep manajemen strategis yang bertujuan untuk penyesuaian penempatan pegawai sesuai talenta. UU ASN secara utuh menegaskan penegakan netralitas PNS yang bebas dari pengaruh politik dan kepentingan. PNS dalam proses pelayanan dilarang untuk berlaku diskriminatif dan bersikap netral dari pengaruh politis, pada kenyataannya banyak terjadi maladministrasi, pelanggaran ini umumnya dilakukan PNS sebelum masa kampanye maupun selama masa kampanye pilkada langsung (Basir, 2009; Leleng et al., 2018; Sutrisno, 2019).
Ledivina Carino telah mengenalkan teori liberal birokrasi. Dalam terma ini, birokrasi tidak pernah lepas dari kendali politik, sehingga PNS tidak mungkin luput dari target agitasi kekerasan psikologis yang terlembaga (Haryatmoko, 2014; Prayitno, 2011). Dominasi dalam birokrasi pada umumnya dilakukan oleh puncak kepemimpinan yang tidak terbatas sebagai pejabat karir, tetapi juga merangkap sebagai pejabat politik yang mencalonkan diri menjadi kepala daerah atau lazim disebut incumbent. Modal simbolik sebagai puncak birokrasi menjadi validasi untuk meligitimasi bawahan. Situasi ini menjadi semakin rentan karena adanya fragmentasi kekuasaan dalam birokrasi yang terkena pengaruh partai politik. Posisi birokrasi yang subordinat, membuat birokrasi lemah dan sulit untuk netral, (Prayitno, 2011).

Pada kenyataannya, di Indonesia terjadi penyeberangan fungsi legislatif dan politisi menuju ranah eksekutif. Kepentingan politik secara laten maupun terang-terangan mengoperasionalkan kehendaknya ke dalam birokrasi (Daniarsyah, 2015; Fakhruddin, 2012). Peserta kontestasi pilkada yang berasal dari petahana kerap menggunakan acara silaturahmi dan kunjungan sebagai strategi pengukuhan kuasa dengan sokongan birokrasi. Sebagaimana panen raya yang terjadi di Kabupaten Bantul. Acara panen raya dijadikan medium kampanye terselubung calon kepala daerah yang melibatkan Kepala Dinas Pertanian dan Kehutanan (Wulandari, 2018). Masalah ini mengkonfirmasi pendapat Bourdieu tentang strategi reproduksi. Bourdieu berpandangan bahwa posisi agen dalam ranah merupakan modal yang terus-menerus diperjuangkan dan ingin dicapai para agen dengan beragam strategi. Para agen, mengonstruksi dunia sosial mereka dan bertindak mempertahankan bahkan mengangkat posisi mereka di dalamnya (Mahar \& Harker, 2010).

Laporan pelanggaran yang diterima Komisi Aparatur Sipil Negara (KASN) dalam kurun waktu tiga tahun dari 2015-2018 menunjukkan pengaduan tidak netralnya PNS pada lebih dari separuh provinsi di Indonesia (Perdana, 2019). Faktor penghambat penegakan azas netralitas PNS adalah lemahnya sistem pengawasan di internal birokrasi dan sanksi untuk penyalahgunaan jabatan (Budiono, 2019).

Kekuasaan selalu berusaha melindungi dirinya sendiri, varian metode dipergunakan untuk tujuan tersebut, bahkan "menjual" kebijakan publik (Nugroho, 2011). Rantai kuasa yang berkelindan antara partai politik, badan legislatif dan kepala daerah membuat PNS dalam pilkada berada pada situasi yang dilematis. Habitus pilkada yang diusung semenjak orde lama maupun orde baru belum terkikis terhadap keberadaan PNS hingga sekarang ini (Yudiatmaja, 2018). Kondisi ini sesuai dengan 
pendapat Bourdieu mengenai habitus. Kendati dalam waktu yang berbeda-beda, sistem yang selalu mewajarkan kesewenangannya akan turut berubahubah agar dapat diterima secara luas (Riawanti, 2017). Kekuasaan selalu menemukan formula, dari hasil pengujian-pengujian kondisi mental dan sosial yang objektif dengan kepentingan yang diusungnya. Sehingga PNS dianggap sebagai klien yang akan selalu patuh pada misi parpol dalam panggung pilkada.

Logika demokrasi langsung saat ini menempatkan masyarakat pada posisi paling bawah dan partai politik (parpol) dalam posisi puncak sebagai produsen kepala dan wakil kepala daerah (Sudrajat \& Karsona, 2016). Parpol yang diharapkan sebagai contoh pembangunan demokrasi juga mengalami kegagalan dalam membangun proses demokrasi di internal partai. Hal ini terlihat dari sikap elit partai melegitimasi calon kandidat yang akan diusung dalam kontestasi. Pada level implementasi, Pilkada langsung yang diharapkan memperkuat nilai-nilai demokrasi justru membawa dampak merosotnya demokrasi karena adanya budaya politik transaksional antara kandidat dengan masyarakat menggunakan politik uang (Alamsyah, 2012; Habibi, 2018; Prayitno, 2011; Wisnumurti, 2012).

Demokrasi dalam pilkada langsung pada praktek demikian menjadi ancaman terhadap makna demokrasi itu sendiri. Permasalahan meningkatnya angka korupsi, degradasi akuntabilitas dan capaian pembangunan daerah terlihat sebagai sesuatu yang lazim. Kepercayaan masyarakat yang rendah terhadap kualitas kepemimpinan dan koreksi rasional terhadap penyelenggaraan pemilihan langsung pada kenyataannya tidak berdampak signifikan terhadap kualitas pemimpin. Hal tersebut ditengarai pola partisipasi vertikal dalam pilkada tidak menyentuh aspek partisipasi ideal. Pilkada langsung dijadikan sarana ajeg relasi kuasa yang tidak tersentuh aspirasi masyarakat (Alamsyah, 2012).

Minimnya partisipasi masyarakat tentunya akan berdampak pada terjadinya indikasi abuse of power. Adanya tindakan penyalahgunaan fasilitas negara dan jabatan untuk kebutuhan kampanye hingga pengerahan PNS mendukung peserta pilkada hingga penggunaan anggaran daerah maupun anggaran negara (Zoelva, 2013). Berdasarkan data Bawaslu, dari tahun 2017-2018 tercatat 70 persen pelanggaran yang dilakukan PNS terkait ketidaknetralannya pada pemilu. Pelanggaran tersebut dilakukan karena adanya desakan pihak lain (Pradana, 2020a).

Rekonstruksi yang nampaknya perlu dibangun oleh Ombudsman dan KASN adalah adanya pemantauan dan memberi sanksi terhadap penyelewengan kepala daerah terpilih. Karena pasca pilkada, selaku patron kebijakan, kepala daerah berpotensi menonjobkan PNS yang tidak mendukungnya (Leleng et al., 2018). Ombudsman dan KASN mesti melihat PNS berada pada posisi abu-abu sebagai penggerak roda pelayanan publik.

Aturan PNS sebagai peserta pemilu yang tertuang pada Undang-Undang Nomor 5 Tahun 2014 tentang Aparatur Sipil Negara dalam proses pemilu sulit diterapkan apabila disandingkan dengan aspek kemanusiaan, karena peraturan tersebut memiliki potensi sebagai perlakuan diskriminatif terhadap profesi PNS (Komalig, 2017). Akan tetapi klaim tersebut dapat segera dibantah apabila merujuk pada tujuan utama netralitas PNS dalam pilkada. Bagaimanapun, seorang aparatur negara bertugas untuk melayani masyarakat. Penegasan larangan berpolitik PNS tertuang pada Peraturan Pemerintah Nomor 11 Tahun 2017 tentang Manajemen PNS tepatnya pada pasal 255. Kendati terbatas pada peraturan spesialisasi PNS terlibat politik praktis, peraturan tersebut merupakan solusi masalah netralitas PNS.

Semenjak orde lama hingga saat ini, perspektif partai politikmenganggap PNS sebagaialatmobilisasi (Sarnawa, 2017). Habitus ini telah menjamur selama sekian dekade, sehingga PNS selalu menjadi kekuatan utama pada setiap kontestasi pemilihan umum. Pada tatanan negara, PNS merupakan pengabdi sipil atau bisa dibaca menjadi sipil yang mengabdi, bukan sebagai tuan bagi sipil (Komalig, 2017). Dengan habitus demikian, secara kelembagaan, PNS berada pada posisi buram. Kegamangan ini mengacu pada aturan yang memberikan PNS hak pilih. Sedangkan kelembagaan TNI maupun Polri secara tegas tidak memiliki hak memilih ataupun dipilih. UndangUndang Nomor 34 Tahun 2004 tentang TNI tertulis. Polri patuh pada Undang-Undang Nomor 2 Tahun 2002 tentang Polri dan Peraturan Pemerintah Nomor 2 Tahun 2003 tentang Peraturan Disiplin Anggota Kepolisian Negara Republik Indonesia. Bagaimanapun, penggunaan hak pilih PNS tidak dapat disingkirkan dari situasi politik praktis secara tegas apabila tidak ada aturan yang mencabut hak tersebut (Sudrajat \& Karsona, 2016).

Keberpihakn PNS pada salah satu calon tidak bisa dilihat sebagai bagian dari anggota masyarakat. Hal ini karena PNS terikat oleh sumpah jabatan yang dilakukan secara sukarela. Artinya, PNS secara total tunduk pada aturan-aturan negara yang berlaku untuknya, sekaligus mendedikasikan tugas untuk pelayanan kepada masyarakat.

Di tengah masyarakat, PNS dianggap sebagai lapisan kelas yang lebih tinggi, tingkah laku seorang PNS dinilai sebagai sebuah contoh. Dengan posisi tersebut, PNS dalam menjalankan tugas mesti bersinergi dengan pimpinan suatu daerah. Bagi masyarakat, tuntutan tugas dan relasi antara 
PNS dengan atasan tidak dapat dikesampingkan pengaruhnya apabila seorang pemimpin mencalonkan diri dalam kontesatasi pilkada. PNS dijadikan acuan oleh masyarakat karena stigma statusnya diasosiasikan dengan golongan priyayi (Amir, 2018; Sudrajat \& Karsona, 2016).

Dengan adanya peluang, PNS berperan mengkomunikasikan gagasan politis, mengarahkan persepsi masyarakat terhadap salah satu peserta pilkada. Bahasa, sebagai simbol kekuasaan tidak pernah berdiri sendiri. Retorika politis dapat meruang dalam konteks lintas budaya. Pengerahan PNS sebagaialat politik dilakukankarena PNS bersentuhan langsung dengan lingkungan masyarakat. Bahasa politis lintas budaya ini dapat dilihat misalnya pada kampanye bernuansa pengajian, (Hartini, 2013; Sudrajat \& Karsona, 2016).

Pada masa pandemi, media sosial menjadi satu-satunya mesin transmisi untuk menopang suara, menyebabkan kendali determinasi PNS dalam Pilkada semakin rumit diawasi. Studi sebelumnya menunjukkan bahwa pandemi menjadi panggung politik yang mengalir dari hulu kepemimpinan seperti Anies Baswedan selaku pemimpin di DKI Jakarta dan Ganjar Pranowo di Kabupaten Jawa Tengah memiliki pengaruh signifikan meningkatkan popularitas calon kepala daerah di tingkat Kabupaten, (Hanafi et al., 2020). Hal serupa berkembang pada tataran lembaga pengawas. Studi di Kalimantan Tengah menunjukkan bahwa Bawaslu fokus pada potensi pelanggaran bantuan sosial untuk kampanye Calon Kepala Daerah, (Sandi \& Suprayitno, 2020). Sementara Kabupaten Pemalang menunjukkan bahwa peran lembaga pengawas pemilu seperti Bawaslu belum menyentuh aspek pelanggaran media sosial secara mendalam. Bawaslu menggunakan internet sebagai media sosialisasi aturan pilkada masa pandemi yang konsen pada penegakan protokol kesehatan bagi para kontestan pilkada (Mutiarasari \& Herawati, 2020).

Berdasarkan evaluasi internal yang dilakukan Bawaslu untuk Kabupaten Lampung menunjukkan bahwa, bentuk pamantauan Bawaslu terhadap netralitas PNS dianggap kurang memadai karena mengacu pada aturan lama (Khoiriyah \& Syarifudin, 2020). Peraturan lama belum memuat keberadaan media sosial sebagai objek pemantauan sehingga membuat upaya pemantauan netralitas PNS menjadi catatan baru pada Pilkada saat ini.

Dengan menggunakan media sosial sebagai proyeksi keberpihakan pada kandidat tertentu, pelayanan publik berada dalam ancaman serius. Belum adanya aturan khusus yang mengatur kampanye media sosial, diikuti pembuatan akun anonim membuat media sosial menjadikan celah pelanggaran netralitas PNS pada pilkada di masa pandemi semakin melebar. Berdasarkan pendapat Muhamad Rezky Pahlawan MP (2019), lemahnya fungsi pengawasan dan sanksi tegas yang melibatkan PNS dalam pilkada membuat budaya pelanggaran netralitas sulit dibersihkan dari tubuh birokrasi. Efek langsung pelanggaran ini adalah terjadinya maladmnisitrasi, tindakan korup, penggunaan fasilitas negara untuk kepentingan pilkada dan pandangan birokrasi sebagai milik kekuasaan tertentu (Lefaan \& Nugroho, 2012; Marwis, 2011; Muksin et al., 2019; Watra, 2020)

Dewasa ini, media sosial menjadi kunci komunikasi politik yang efektif dan efisien. Media sosial telah menjadi saluran kedua penyebaran informasi maupun komunikasi secara real time, (Sudibyo, 2019). Akurasi ruang virtual ditengarai lebih efektif dan hemat biaya daripada menggunakan fasilitas ruang publik.

Pada studi berbeda menunjukkan bahwa kekalahan salah satu Calon anggota legislatif disebabkan oleh tidak optimalnya manajemen komunikasi tim melalui media sosial (Alfiyani, 2018). Pada tahun 2018, KASN mencatatkan bahwa pengaduan pelanggaran netralitas PNS di 28 Provinsi mencapai 951 pelanggaran dengan Provinsi tertinggi, yakni Sulawesi Selatan dengan jumlah 294, disusul Provinsi Sulawesi Tenggara 221, Jawa Barat 54, Maluku Utara 41, Lampung 40, Riau 38, Jawa Tengah 29, Jambi 25, Sumetara Selatan 24, Sulawesi Barat 21, Kalimantan Selatan 21, NTT 20, Sumetera Utara 18, Sulawesi Utara 17, Sumatera Barat 16, NTB 11, Kalimantan Timur 11, Jawa Timur 9, Gorontalo 7, Kalimantan Barat 7, Kalimantan Tengah 7, Maluku 5, Bali 4, Papua 4, Banten 3, Sulawesi Tengah 2, DKI Jakarta 1, Kalimantan Utara 1 (Mokhsen et al., 2018). Sementara pada tahun 2020, berdasarkan rilis KASN, laporan pelanggaran netralitas PNS hingga 13 Juni sejumlah 413 PNS (Khoiriyah \& Syarifudin, 2020). Data tersebut mencakup pelanggaran netralitas PNS melalui media sosial dengan persentase $18,7 \%$. Sedangkan tujuan utama pelanggaran meliputi tujuan materialistis, cetak biru, dan menghindari non-job sebesar $43,4 \%$.

\section{Strategi Pemulihan Netralitas PNS}

Demokrasi dalam pilkada langsung dan serentak di beberapa daerah menunjukkan habitus PNS yang diposisikan sebagai mesin politik pilkada tidak dapat dipungkiri adanya. Beberapa catatan buruk pilkada mengindikasikan bahwa pembuatan keputusan dikuasai kelompok profesional yang tertarik pada keuntungan dan kepentingan mereka sendiri ketimbang kepentingan publik yang mereka layani. Skema ini menjadi perangkap bagi PNS sehingga tidak bisa lepas dari jerat keberpihakan pada kandidat pilkada. Sehingga rasionalitas kebijakan netralitas PNS kemudian terfragmentasi. 
Keterbatasan tersebut terjadi karena minimnya perhatian pada masalah yang harus ditangani dalam periodisasi waktu yang anomali, (Parsons, 2011). Ancaman netralitas PNS dalam pilkada pada masa pandemi dengan demikian menjadi pekerjaan berat bagi hampir semua lembaga evaluator pada sebelum, menjelang, hingga setelah pilkada dilaksanakan.

Persoalan di masa mendatang, moralitas PNS menjaga netralitasnya akan menjadi sulit diaplikasikan. Kemajuan teknologi telah merengkuh semua aspek sosial maupun politik. Terlebih, sistem daring sebagai satu-satunya sarana kampanye rentan dijadikan PNS pijakan untuk mendukung paslon. Sehingga pemerintah, selain melakukan pengawasan dalam lingkungan birokrasi, pemerintah mesti melibatkan kementerian komunikasi dan informasi dalam upaya pengawasan.

Studi terdahulu menunjukkan bahwa pengawasan tidak netralnya PNS dapat diatasi dengan tiga koridor. Pertama, penegakan aturan secara tegas baik sebelum maupun pasca pilkada (Basir, 2009). Kedua, Implementasi peraturan harus ditopang sosialisasi, pembinaan secara kuratif (Bahrul, 2015). Ketiga, melalui check and balance secara berkesinambungan terkait pemindahan dan pengangkatan PNS menyangkut jabatan struktural (Aminudin et al., 2016). Untuk tujuan tersebut kemudian pemerintah membentuk lembaga independen Komisi Aparatur Sipil Negara (KASN). UU ASN pada Pasal 27 dan Pasal 28 menggariskan KASN dibentuk sebagai lembaga nonstruktural yang independen dan bertugas menjaga harkat, martabat dan marwah ASN untuk selalu berlaku netral untuk kepentingan negara. Akan tetapi, dalam pelaksanaan tugas tersebut KASN belum tersebar di daerah. KASN berkantor di ibukota menyebabkan tidak optimalnya kinerja KASN di daerah. Sehubungan dengan tantangan tersebut, KASN bekerja sama lintas instansi, misalnya kerjasama dengan Badan Pengawas Pemilu (Bawaslu) Kementerian Dalam Negeri dan Kementerian Aparatur Negara dan Reformasi Birokrasi (Perdana, 2019). Kendala kekurangan SDM, kantor yang belum definitif juga dihadapi Ombudsman yang memiliki kewenangan menindaklanjuti perbuatan maladministrasi, (Yusriwan et al., 2018). Sebagaimana telah ditegaskan dalam pasal 7 Undang-Undang Nomor 37 Tahun 2008 tentang Ombudsman Republik Indonesia, dimana salah satu tugasnya adalah melakukan upaya pencegahan maladminsitrasi dalam penyelenggaraan pelayanan publik. Kurangnya kuantitas SDM maupun kantor Ombudsman yang belum definitif menyebabkan fungsi pengawasan dirasakan belum optimal. Dalam suatu kontestasi, para calon Kepala Daerah membutuhkan dukungan, begitu juga dengan para PNS berharap akan mendapatkan "job" jika calon Kepala Daerah yang mereka dukung dapat memenangkan Pilkada, hal ini terusmenerus berulang dan berdampak kepada layanan di masyarakat yang bisa terhambat (Septiawan, 2020).

Pelanggaran netralitas PNS tidak dapat dilihat dari perspektif monokausalitas. Sejarah membentuk eksistensi habitus bahwa birokrasi menjadi bagian pemerintah, sehingga mengekspresikan PNS sebagai sumbu politik praktis. Praktik keberpihakan PNS pada calon tertentu semakin terlihat pada masa pandemi, sebagian besar PNS menggunakan media sosial sebagai motor kampanye. Seperti diketahui bencana non alam Coronavirus telah mengemparkan dunia sejak awal tahun 2020, virus ini diduga bermula di salah satu pusat pasar makanan laut yang ada di Kota Wuhan, Cina (Ilham et al., 2020), hal ini kemudian direspon pemerintah dengan kebijakan penerapan kebijakan social distancing menyusul physical distancing yang mengharuskan semua aktivitas dilakukan dari rumah (work from home) sebagai upaya menekan laju penyebaran virus tersebut, (Ilham et al., 2020). Untuk menghindari kerumunan begitu juga dengan mobilitas orang, pelaksanaan kampanye melalui media social sebagai upaya menarik simpatik masyarakat kemudian gencar dilakukan. Kampanye melalui media social telah menjadi pilihan pada perhelatan Pilkada serentak 2020 di tengah merebaknya pandemic Covid-19 di tanah air. Hal ini kemudian membuka celah bagi para ASN untuk turut terlibat dalam mensosialiasikan kandidat tertentu. Berdasarkan pemberitaan yang dirilis Kompas.com, Ketua KASN Agus Pramusinto mengatakan bahwa top 5 (lima) kategori jenis pelanggaran ASN adalah kampanye atau sosialisasi di media social, yakni 27\%, (Farisa, 2020).

Secara aturan, UU No. 10 Tahun 2016 tentang Perubahan Kedua UU No. 1 Tahun 2015 tentang Pemilihan Gubernur, Bupati, dan Walikota Menjadi Undang-Undang, tidak secara tegas memuat aspek media sosial sebagai sasaran pengawasan. Akan tetapi, Peraturan Bawasu No. 6 Tahun 2018 secara tegas menyebutkan bahwa bentuk keberpihakan mencakup ajakan dan imbauan di lingkungan kerja ASN, Anggota TNI, Anggota Polri. Peraturan tersebut dikuatkan Pasal 28 ayat (1) huruf e UU No.1 Tahun 2015 yang memberikan peluang kepada Bawaslu untuk menindaklanjuti temuan yang bukan kewenangannya kepada instansi berwenang. Kedua regulasi tersebut dapat dijadikan pedoman bagi pengawas pemilu untuk memantau netralitas PNS dalam media sosial.

Media sosial sebagai pantulan mekanisme sistem sosial maupun kenyataan politik praktis menyodorkan kepada kita bahwa kekerasan simbolik terjadi karena desakan luar diri pelaku. Berdasarkan 
data yang diperoleh hingga September 2020 terdapat 694 ASN yang dilaporkan mekakukan pelanggaran netralitas, (Mashabi, 2020). Beberapa penyebab ketidaknetralan ASN tersebut, juga disampaikan Menteri Pendayagunaan Aparatur Negara dan Reformasi Birokrasi (MenPANRB) Tjahjo Kumolo dalam Webinar Netralitas ASN dalam Pilkada Serentak bahwa masih ada usaha upaya 'intervensi' atau tekanan dari atasan, termasuk kurang integritas, dan juga ketidaknetralan ASN masih dianggap suatu hal yang lumrah (Raharjo \& Sari, 2020).

Aspek moralitas hanya dapat dibangun dari dalam diri PNS melalui institusionalisasi aturan yang tegas. Secara historis, pemilu telah menunjukkan bahwa birokrasi sebagai struktur yang memberi ruang untuk kekerasan simbolik bertahan sekian dekade (Sarnawa, 2017). Perspektif ini menjadi argumen bahwasanya pelanggaran netralitas bukan melihat PNS sebagai subjek pelanggaran, tetapi objek dari habitus kekerasan struktural. Aspek legalitas tanpa memberi perhatian pada segi perlindungan kepada manusia tentu tidak akan menurunkan pelanggaran (Suseno, 2016). Sisi utuh seseorang, termasuk PNS tidak menjadikan sarana normatif sebagai panduan, tetapi mereka cenderung beradaptasi dengan mekanisme kekuasaan yang tengah berlangsung. Pada pilihan dilematis, orang sering memakai minus malum, mengambil yang baik dari semua pilihan buruk, (Haryatmoko, 2014). Simpul kuasa yang terjadi dalam struktur birokrasi dapat dikerat dengan beragam metode. Pertama, pencabutan hak pilih dan memilih PNS. Secara substansial, posisi hukum positif dan politik terpisah satu sama lain (Sudrajat \& Karsona, 2016). Muatan hukum positif mengatur sikap, tanggung jawab maupun hak PNS sebagai komponen birokrasi yang bebas dari skema politik. Sehingga pencabutan hak pilih dan memilih PNS menjadi metode rasional untuk mencegah keterlibatan PNS dalam pilkada. Kedua, melalui manajemen akuntabilitas, karena idealitas birokrasi sebagai wahana manajemen akuntabilitas yang tunduk pada tanggung jawab melayani masyarakat (M. H. Basri, 2017; Daniarsyah, 2015; Haryatmoko, 2014) Ketiga, penting dilakukan pemisahan struktur secara tegas antara birokrasi dengan parpol, (Prayitno, 2011; Rakhmawanto, 2017; Ramadhanti, 2018; Yudiatmaja, 2018) Pemisahan birokrasi dengan politik karena pilkada langsung secara esensi memiliki perbedaan dengan pemilihan anggota legislatif (Pileg). Kontestan yang terpilih dalam pilkada sangat memengaruhi posisi PNS pada masa mendatang. Sementara Pileg tidak memiliki dampak signifikan terhadap PNS. Dengan adanya pemisahan koridor birokrasi dengan parpol, akan memberi peluang dilakukannya upaya sterilisasi birokrasi dari intervensi parpol.

\section{SIMPULAN}

Berdasarkan penelitian ini, kekerasan simbolik terhadap PNS seringkali terjadi secara semu, sehingga berada dalam belenggu kekuasaan yang secara historis seringkali tidak memberikan pilihan selain tunduk pada lingkaran elit. Ambiguitas posisi tersebut menyebabkan integritas PNS untuk netral dalam pilkada diuji. Pada masa pandemi, media sosial menjadi satu-satunya sarana kampanye potensial bagi para kandidat di tengah pembatasan jarak fisik. Belum optimalnya fungsi pemantauan aktifitas di ruang siber semakin menghambat implementasi netralitas PNS.

Upaya preventif yang dapat dilakukan untuk relasi politis adalah melalui sisi kebijakan publik yang merancang secara legal pembatasan hak pilih dan hak memilih PNS untuk melandasi kepatuhan yang diikuti penegakan sanksi sebagaimana diatur PP No. 42/2004 tentang Pembinaan Jiwa Korps dan Kode Etik PNS dan PP No. 53/2010 tentang Disiplin PNS, UU No.5/2015 tentang Aparatur Sipil Negara. Berdasarkan kajian sosio-kultural, belum ada kemungkinan akan berkurangnya pelanggaran netralitas. Sistem oposisi dua aras dinilai rasional untuk pengaturan internal birokrasi, mencakup aspek moralitas dan profesionalisme PNS sehingga mengawetkan tugas pokok terbatas sebagai pelayan publik, dan bukan bagian utuh masyarakat. Selanjutnya perlu adanya perekatan konsolidasi lembaga-lembaga pengawas baik menjelang pilkada maupun setelah pilkada yang mengacu pada pemantauan aktifitas akun media sosial, peraturan dan laporan masyarakat untuk membatasi ruang gerak PNS turut serta dalam pilkada.

\section{DAFTAR PUSTAKA}

Agustino, L. (2017). Politik Lokal dan Otonomi Daerah. Alfabeta.

Alamsyah, M. N. (2012). Fenomena Electocracy dalam Pilkada Langsung di Indonesia. Jurnal Academica, 4(1), 761-773.

Alfiyani, N. (2018). Media Sosial sebagai Strategi Komunikasi Politik. Potret Pemikiran, 22(02), 57-69.

Aminudin, M., Sumartono, \& Domai, T. (2016). Mengurai Inersia Nir-Netralitas dan Segregasi Paska Pilkada. Jejaring Dministrasi Publik, 8(1), 838-846.

Amir, M. (2018). Konsep Netralitas terhadap Ketentuan Pelanggaran Disiplin Aparatur Sipil Negara. Petitum, 6(2), 87-97.

Arrsa, R. C. (2014). Pemilu Serentak dan Masa Depan Konsolidasi Demokrasi. Jurnal Konstitusi, 11(3), 515-537. 
Bahrul, B. (2015). Meneguhkan Netralitas, Mematri Imparsialitas. Jurnal Etika \& Pemilu, 1(3), 42-55.

Basir, G. (2009). Birokrasi dan Kekuasaan Politik: Partisipasi Birokrat dalam Pemilihan Kepala Daerah. Al-Hurriyah, 10(1), 55-63.

Basri, M. H. (2017). Kontrol Politik Birokrasi dalam Kebijakan Publik. Publisia (Jurnal Ilmu Administrasi Publik), 2(2), 121-129.

Bimantara, N., \& Harsasto, P. (2018). Analisis Politik Dinasti di Kabupaten Kediri. Journal of Politic and Government Studies, 7(4), 201-210.

Budiono. (2019). Asas Netralitas Aparatur Sipil Negara Pada Pemilukada (Studi Penerapan Pasal 2 Huruf F UU RI Nomor 5 Tahun 2014 tentang Netralitas ASN di Kabupaten Tulungagung). Mizan: Jurnal Ilmu Hukum, 8(2), 129-137.

Creswell, J. W. (2009). Research Design Qualitative, Quantitatif dan Mixed. In A. Fawaid (Ed.), Terjemahan (Edisi Ketiga). Pustaka Pelajar.

Daniarsyah, D. (2015). Bureaucratic Political and Neutrality of Bureaucracy in Indonesia. Jurnal Ilmu Politik Dan Komunikasi, 5(2), 85-94.

Dharmaningtias, D. S. (2020). Netralitas Aparatur Sipil Negara. Info Singkat Bidang Politik Dalam Negeri, 12(17), 25-29.

Dompas, P. A. M. (2016). Aspek Penegakan Disiplin Aparatur Sipil Negara Berdasarkan Peraturan Perundang-Undangan. Lex et Societatis, 4(5), 62-70.

Fakhruddin, M. A. (2012). Model Hubungan antara Birokrasi dan Politisi di Indonesia. Jurnal Review Politik, 2(2), 282-301.

Farisa, F.C. (2020). Mayoritas ASN Langgar Netralitas Lewat Kampanye di Media Sosia. Kompas.com,https://nasional.kompas.com/ $\mathrm{read} / 2020 / 06 / 30 / 12190851 /$ mayoritas-asnlanggar-netralitas-lewat-kampanye-di-mediasosial?page $=$ all

Gedeona, H. T. (2013). Birokrasi dalam Praktiknya di Indonesia: Netralitas atau Partisan. Jurnal Ilmu Administrasi, 10(2), 232-245.

Habibi, M. (2018). Peran Uang dalam Penyelenggaraan Demokrasi Elektoral di Indonesia. https://doi.org/10.5281/ zenodo. 1256963

Hafidz, M., Muntafa, F., Muldi, A., Nuraharjo, A., Seftyono, C., Zaid, M., Ihsan, M., \&
Aritonang, D. (2020). Indeks Kerawanan Pemilu (IKP) Pilkada Serentak 2020 (T. E. B. RI (ed.)). Badan Pengawas Pemilihan Umum Republik Indonesia.

Hamzah, A. (2020). Metode Penelitian Kepustakaan: Kajian Filosofis, Aplikasi, Proses, dan Hasil Penelitian. Literasi Nusantara.

Hanafi, R. I., Syafii, I., Ramadhan, M. S., \& Prayoga, P. (2020). Kepemimpinan Lokal di Masa Pandemi Covid-19: Respons, Kebijakan, dan Panggung Elektoral. Jurnal Penelitian Politik, 17(2), 195-218.

Haris, S. (2014). Masalah-Masalah Demokrasi Kebangsaan Era Reformasi. Yayasan Obor.

Hartini, L. (2013). Campur Kode sebagai Simbol Kekuasaan dalam Pilkada Kabupaten Bandung (Tinjauan Komunikasi Lintas Budaya). Jurnal Wawasan Hukum, 29(2), 868-882.

Hartini, S., Kadarsih, S., \& Sudrajat,T. (2014). Kebijakan Netralitas Politik Pegawai Negeri Sipil dalam Pemilukada: Studi di Jawa Tengah. Jurnal Ilmu Hukum, 1(3), 537-557.

Haryatmoko. (2014). Etika Politik \& Kekuasaan. Penerbit Buku Kompas.

Hidayat, R. N. (2020). Penggunaan Buzzer Politik di Media Sosial Pada Masa Kampanya Pemilihan Umum. 'Adalah, 4(2), 29-38. https://doi.org/10.15408/adalah.v4i2.15606.

Ilham, I., Idris, U., \& Muttaqin, M.Z. (2021). Pandemi di Ibu Pertiwi: Kajian Literatur "Penanganan Pandemi Covid-19 di Indonesia". Banda Aceh: Syiah Kuala University Press.

Ilham, I., Muttaqin, M.Z., Usman, I., \& Suryanti, M.S.D. (2020). Kondisi Pengusaha Indonesia Ditengah Pandemi Covid-19. Civic-Culture: Jurnal Ilmu Pendidikan PKn dan Sosial Budaya, 4(1)59-68. https://doi.org/10.31597/ cc.v4i1.379

Ismail, M. Z. (2014). Pemilihan Kepala Daerah Secara Langsung sebagai Momentum Strategis dalam Pengembangan Otonomi Daerah dan Demokrasi Lokal. Jurnal Valid, $11(2), 57-72$.

Khoiriyah, F., \& Syarifudin, A. (2020). Optimalisasi Fungsi Pengawasan Bawaslu terhadap Netralitas Aparatur Sipil Negara di Media Sosial. In A. Mellaz, B. Sujadmiko, Z. Ridlwan, \& A. Triono (Eds.), Serial Evaluasi Pilkada Serentak di Indonesia: Bawaslu Provinsi Lampung. Bawaslu. 
Komalig, K. R. (2017). Hak Politik Aparatur Sipil Negara Berdasarkan Undang-Undang Nomor 5 Tahun 2014. Lex Crimen, 6(4), 151-157.

Lefaan,A., \& Nugroho, H. (2012). Etnosentrisme Dan Politik Representasidi Era Otonomi Khusus Papua. Majalah Ilmiah Pembelajaran, O(0).

Leleng, L. I. V., Liando, D., \& Kairupan, J. (2018). Netralitas Aparatur Sipil Negara pada Pelaksanaan Pemilihan Umum Kepala Daerah tahun 2015. Jurnal Jurusan Ilmu Pemerintahan, 1(1), 1-12.

Lengkong, J. P., Purwanto, \& Kaunang, M. (2017). Netralitas Pegawai Negeri Sipil Dalam Pemilihan Umum Kepala Daerah Provinsi Gorontalo Tahun 2017. Jurnal Administrasi Publik, 4(62), 26-35.

Mahar, C., \& Harker, R. (2010). Habitus X Modal + Ranah = Praktik: Pengantar Paling Komprehensif kepada Pemikiran Pierre Bourdieu. Jalasutra.

Mardiana, M. (2020). Politisasi Perekrutan Anggota Badan Penyelenggara Pemilu Ad Hoc: Studi Kasus di Kabupaten Tanjung Jabung Timur, Jambi. Politika: Jurnal Ilmu Politik,11(1), 96106

Martini, R. (2010). Politisasi Birokrasi Di Indonesia. POLITIKA: Jurnal Ilmu Politik, 1(1), 67-74.

Marwi, A. (2016). Kewenangan Penjabat Kepala Daerah di Bidang Kepegawaian dalam Menyelenggarakan Pemerintahan Daerah (Studi pada Pemerintahan Kota Mataram). Jurnal IUS, 4(3), 540-555.

Marwis. (2011). Analisis Kampanye Politik terhadap Sikap Pemilih PNS Kantor Sekretariat Daerah Kabupaten Soppeng pada Pilkada tahun 2005. Jurnal Komunikasi KAREBA, 1(4), 382-393.

Mokhsen, N., Dwiputrianti, S., \& Muhammad, S. (2018). "Pengawasan Netralitas Aparatur Sipil Negara". Jakarta:Komisi Aparatur Sipil Negara.

Moleong. (2005). Metodologi Kualitatif. PT Remaja Rosdakarya.

Muhamad Rezky Pahlawan MP. (2019). Netralitas Pegawai Negeri Sipil Pada Pelaksanaan Pemilihan Umum. Jurnal Surya Kencana Satu: Dinamika Masalah Hukum Dan Keadilan, 10(2), 135-149.

Muksin, D., Purwaningsih, T., \& Nurmandi, A. (2019). Praktik Dinasti Politik di Aras Lokal Pasca Reformasi: Studi Kasus Abdul Gani Kasuba dan Ahmad Hidayat Mus Pada Pilkada Provinsi Maluku Utara. Jurnal Wacana Politik, 4(2), 133-144.
Mutiarasari, N. N., \& Herawati, R. (2020). Supervision of Bawaslu Pemalang Regency in the 2020 Regional Head Election. Law Reform, 16(2), 264-275.

Nisa, C. U., Disemadi, H. S., \& Roisah, K. (2020). Aspek Hukum Tentang Black Campaign Pada Platform Media Sosial Instagram. Mahkamah : Jurnal Kajian Hukum Islam, 5(1), https://doi. org/10.24235/mahkamah.v5i1.6032

Nugroho, R. (2011). Public Policy (Edisi keti). PT Elex Media Komputindo.

Parsons, W. (2011). Public Policy: pengantar Teori \& Praktik Analisis Kebijakan (T. W. B. Santoso (ed.); terjemahan). Kencana Prenada Media Group.

Perdana, G. (2019). Menjaga Netralitas ASN dari Politisasi Birokrasi. Negara Hukum, 10(1), 109-128.

Pradana, J. (2020a). Terpaksa, 70 Persen ASN Tak Netral dalam Pilkaada Karena. Bawaslu. Go.Id. https://www.bawaslu.go.id/id/berita/70persen-asn-tak-netral-dalam-pilkada-karenaterpaksa/

Pradana, J. (2020b). Verfak Calon Perseorangan Bawaslu Temukan Puluhan Ribu Dukungan dari ASN dan Penyelenggara Pilkada. Bawaslu.go.id. https://www.bawaslu.go.id/ $\mathrm{id} /$ berita/verfak-calon-perseorangan-bawaslutemukan-puluhan-ribu-dukungan-dari-asndan-penyelenggara/

Pratama, R. . (2017). Patronase dan Klientalisme pada Pilkada serentak Kota Kendari tahun 2017. Jurnal Wacana Politik, 2(1), 33-45.

Prayitno, B.(2011). Birokrasidan Politik: Problematika dalam Keniscayaan Administrasi Publik. Junral Wacana Kinerja, 14(1), 133-149.

Prihatin, E. S. (2014). Politik Hukum Otonomi Daerah tentang Pemilukada. MasalahMasalah Hukum, 43(1), 49-56.

Rakhmawanto, A. (2017). Perspektif Politisasi Birokrasi dan Peran Pejabat Pembina Kepegawaian dalam Birokrasi Pemerintah. JAKP: Jurnal Administrasi Dan Kebijakan Publik, 3(1), 19-32.

Ramadhan. (2020, July 1). Polemik Penghapusan Hak Suara ASN/PNS. Asumsi.Co. https:// www.asumsi.co/post/polemik-penghapusanhak-suara-pns/

Ramadhanti, R. (2018). Politik dan Birokrasi Pemerintahan. Jurnal Trias Politika, 2(1), 96-104. 
Rayadi, R. M., \& Erman. (2014). Politisasi Birokrasi Pada Pemilihan Umum Kepala Daerah (Studi Mobilisasi Pegawai Negeri Sipil Di Pemerintah Daerah Kabupten Siak Tahun 2011). Jurnal Online Mahasiswa, 1(1), 1-14.

Razak, F. S. H. (2015). Kuasa Wacana Kebudayaan Bugis Makassar dalam Pilkada Di Kabupaten Pinrang: Implementasi Nilai-Nilai Sipakatau, Sikainge dan Sipalakelebbi dalam Memobilisasi Massa pada Pilkada Pinrang Tahun 2013. Jurnal Politik Profetik, 5(1), 16-35.

Riawanti, S. (2017). Teori tentang Praktik: Saduran Outline of a Theory of Practice Karya Pierre Bourdieu. Ultimus.

Ristyawati, A. (2020). Efektivitas Pelaksanaan Pilkada Serentak 2020 Pada Masa Pandemi Darurat Covid-19 Di Indonesia. Crepido, 2(2), 85-96. https://doi.org/10.14710/ crepido.2.2.85-96

Russell, B. (2019). Kekuasaan: Sebuah Analisis Sosial dan Politik(H. Basri (ed.); Terjemahan). Yayasan Obor Indonesia.

Sandi, J. R. A., \& Suprayitno, S. (2020). Fenomena Pengawasan Pemilihan Kepala Daerah Di Kalimantan Tengah Masa Pandemi Covid-19. Jurnal Politik Pemerintahan Dharma Praja, 13(1), 1-13.https://doi.org/10.33701/jppdp. v13i1.1072

Sarnawa, B. (2017). Pengaturan dan Implementasi Prinsip Netralitas Aparatur Sipil Negara di Indonesia. Jurnal Media Hukum, 24(1), 42-51.

Snook, I. (2009). Bahasa, Kebenaran, dan Kekuasaan: Ministerium Bourideu. In S. Rahmana (Ed.), Habitus $x$ modal + Ranah $=$ Praktik: pengantar Paling Komprehensif kepada Pemikiran Pierre Bourdieu (Terjemahan, p. 221). Jalasutra.

Solihah, R. (2016). Pola Relasi Bisnis Dan Politik Di Indonesia Masa Reformasi: Kasus Rent Seeking. Jurnal Wacana Politik, 1(1), 41-52. https://doi.org/10.24198/jwp.v1i1.10546

Sudibyo, A. (2019). Jagat Digital: Pembebasan dan Penguasaan. KPG (Kepustakaan Populer Gramedia).

Sudrajat, T., \& Karsona, A. M. (2016). Menyoal Makna Netralitas Pegawai Negeri Sipil dalam Undang-Undang Nomor 5 Tahun 2014 tentang Aparatur Sipil Negara. Jurnal Media Hukum, 88-94. https://doi.org/10.18196/ jmh.2015.0070.87-94

Sugiono, S. (2020). Fenomena Industri Buzzer Di Indonesia: Sebuah Kajian Ekonomi Politik Media.Communicatus: JurnalllmuKomunikasi,
4(1)， 47-66. https://doi.org/10.15575/cjik. v4i1.7250

Suseno, F. M. (2016). Etika Politik: Prinsip Moral Dasar Kenegaraan Modern (Revisi). PT Gramedia.

Sutrisno. (2019). Prinsip Netralitas Apartur Sipil Negara dalam Pemilihan Kepala Daerah. $J H$ Ius Quia Iustum, 26(3), 521-543.

Wasisto, A., \& Prayudi. (2020). Antisipasi Implikasi Demokratis Pilkada Serentak Tahun 2020. Bidang Politik Dalam Negeri Info SIngkat, 12(12), 25-30.

Watra, B. L. (2020). Ombudsman Ingatkan Potensi Maladministratif pada Pilkada Serentak 2020. AntaraNews. https://m.antaranews.com/ amp/berita/1529196/ombudsman-ingatkanpotensi-maladministratif-pada-pilkadaserentak-2020/

Wisnumurti, A. A. G. O. (2012). Relasi uasa Penguatan Demokrasi Lokal di Bali. Udayana University Press.

Wulandari, W. (2018). Netralitas Aparatur Sipil Negara (ASN) dalam Pilkada Serentak Kabupaten Bantul Tahun 2015. In T. N. Haryani (Ed.), Seminar Nasional Administrasi Publik: Relasi Governansi dalam Agenda Reformasi Birokrasi Multidimensional di Indonesia (pp. 264-271). Universitas Sebelas Maret.

Yudiatmaja, W. E. (2018). Politisasi Birokrasi: Pola Hubungan Politik dan Birokrasi di Indonesia. Jurnal Ilmu Administrasi Negara, 3(1), 1028.

Yuniningsih, T. (2018). Peran Etika dan Integritas Aparatur Sipil Negara dalam Mewujudkan "Clean and Prestigious Buereucracy." In T. Yuniningsih (Ed.), Etika Administrasi Publik (pp. 1-64). Program Studi Doktor Administrasi Publik Fisip Undip.

Yusriwan, T. F., Taqwaddin, \& Efendi. (2018). Peran Ombudsman RI Perwakilan Aceh dalam Pengawasan Kinerja Pemerintah di Kota Banda Aceh. Syiah Kuala Law Journal, 2(3), 354-370.

Zoelva, H. (2013). Memberantas Electoral Corruption. In Jurnal Pemilu \& Demokrasi (p. 3). Yayasan Perludem.

Zulhair, M. (2018). Bourdieu dan Hubungan Internasional: Konsep, Aplikasi, dan Filsafat Ilmu. Jurnal Transformasi Global, 3(2), 125144. 